\title{
LITERASI DIGITAL DAN ETIKA BERMEDIA SOSIAL KALANGAN PELAJAR DI SMAN WIRA BANGSA ACEH BARAT
}

\author{
Khori Suci Maifianti ${ }^{1}$, Rahma Hidayati ${ }^{2}$, Fiandy Mauliansyah ${ }^{3}$ \\ ${ }^{1}$ Program Studi Agribisnis, Fakultas Pertanian, Universitas Teuku Umar \\ ${ }^{23}$ Program Studi Ilmu Komunikasi, Fakultas ISIP, Universitas Teuku Umar \\ e-mail: Fiandymauliansyah@gmail.com
}

\begin{abstract}
Abstrak
Di zaman sekarang, perkembangan literasi digital berkembang cukup pesat. Dalam literasi digital itu bukan hanya sekedar kemampuan mencari, menggunakan dan menyebarkan informasi akan tetapi, diperlukan kemampuan dalam membuat informasi dan evaluasi kritis, ketepatan aplikasi yang digunakan dan pemahaman mendalam dari isi informasi yang terkandung dalam konten digital tersebut. Di sisi lain literasi digital mencakup tanggung jawab dari setiap penyebaran informasi yang dilakukannya karena menyangkut dampaknya terhadap masyarakat. Penyuluhan tentang pentingnya literasi digital dan kesadaran etika dalam bermedia sosial ini dilaksanakan pada bulan April 2021 lalu. Bertempat di Aula Utama Sekolah SMAN Wira Bangsa Aceh Barat, kami mengajak para siswa untuk berdiskusi sambil bermain tentang fenomena media sosial. Hasil dari kegiatan ini menunjukkan bahwa meskipun penggunaan media sosial memberi dampak positif, perkembangan media sosial ternyata juga dapat memberikan dampak negatif. Anak maupun remaja memiliki keterbatasan untuk melakukan regulasi diri. Mereka juga rentan mendapatkan tekanan dari teman sebaya sehingga mereka memiliki resiko tinggi terpapar dampak negatif dari penggunaan media sosial. Penelitian menunjukkan bahwa ada beberapa resiko yang mungkin didapatkan seperti terpaparnya konten pornografi atau konten negatif lain dan kurangnya pemahaman mengenai isu privasi.
\end{abstract}

Kata kunci: Literasi Digital, Media Sosial, Remaja.

\begin{abstract}
On this day, the development of digital literacy is growing quite rapidly. In digital literacy, it is not just the ability to find, use and disseminate information, it requires the ability to make information and critical evaluation, the accuracy of the application used and a deep understanding of the information content contained in the digital content. On the other side, digital literacy includes the responsibility of any dissemination of information it does because it involves its impact on society. Located in the Main Hall of SMAN Wira Bangsa Aceh Barat School, we invite students to discuss while playing about the phenomenon of social media. The results of this activity show that although the use of social media has a positive impact, the development of social media can also have a negative impact. Children and adolescents have limitations to self-regulation. They are also vulnerable to peer pressure so they have a high risk of being exposed to the negative impacts of using social media. Research shows that there are several possible risks such as exposure to pornographic content or other negative content and a lack of understanding of privacy issues.
\end{abstract}

Keywords: Digital Literacy, Social Media, Youth.

\section{PENDAHULUAN}

Salah satu yang menjadi perhatian di banyak kalangan akhir akhir ini adalah persoalan literasi digital. Konsep yang popular di kalangan para akademis di tahun 2005 ini sering menjadi perbincangan akibat dari perkembangan teknologi informasi yang kian canggih. Perkembangan teknologi informasi semacam ini menuntut setiap subjek penggunan teknologi informasi memiliki kemampuan dalam pemahaman mengenai literasi digital tersebut. Pengetahuan tentang literasi di zaman sekarang sangatlah diperlukan untuk menandakan maju atau tidaknya sebuah bangsa. 
Di zaman sekarang, perkembangan literasi digital berkembang cukup pesat. Seiring dengan perkembangan teknologi tersebut banyak negara-negara sudah mulai berupaya untuk meningkatkan kesadaran warga dengan kemampuan literasi digital. Akan tetapi, menurut hasil survey yang dilakukan, Indonesia masih berada diperingkat 60 dari 61 dari Negara yang membudayakan literasi. Angka itu cukup mengkhawatirkan ditambah ketika Bank Dunia melaporkan bahwa sebanyak 55\% dari warga Indonesia memiliki tingkat buta huruf dari keseluruhan populasi penduduk.

Diperlukan pemahaman mendalam bahwa literasi digital sangat erat hubungannya dengan kegiatan sehari-hari. Dalam hal ini literasi tidak hanya berpusat pada kegiatan membaca dan menulis saja (White, 2008; Santosa, 2012; Safila \& Guardian, 2015; Nurkhasanah \& Guardian, 2015). Ada tujuan lain yang ingin diraih dengan bantuan kegiatan membaca dan menulis, dan tujuan ini berkaitan erat dengan hubungan sosial yang lebih luas. Dalam pandangan sosial, literasi tidak hanya berfokus pada pada kemahiran individu dan penggunaan keterampilan tersebut, namun lebih pada bagaimana memanfaatkan praktik literasi dalam kehidupan seharihari.

Literasi digital menjadi kebutuhan mendesak bagi masyarakat saat ini. Sebab kemajuan teknologi yang tidak diimbangi oleh kecerdasan dalam menggunakan perangkat teknologi modern, niscaya akan memberikan dampak buruk bagi peradaban manusia. Dalam literasi digital itu bukan hanya sekedar kemampuan mencari, menggunakan dan menyebarkan informasi akan tetapi, diperlukan kemampuan dalam membuat informasi dan evaluasi kritis, ketepatan aplikasi yang digunakan dan pemahaman mendalam dari isi informasi yang terkandung dalam konten digital tersebut. Di sisi lain literasi digital mencakup tanggung jawab dari setiap penyebaran informasi yang dilakukannya karena menyangkut dampaknya terhadap masyarakat. Literasi digital juga menjadi bagian dari rencana jangka panjang badan PBB yang mengurusi soal pendidikan dan kebudayaan. Dalam roadmap UNESCO (2015-2020), literasi digital menjadi pilar penting untuk masa depan pendidikan. Literasi digital menjadi basis pengetahuan, yang didukung oleh teknologi informasi secara terintegrasi.

Untuk Indonesia kebutuhan mendorong literasi sosial sudah sangat mendesak, mengingat bahwa penduduk yang bergerak "bermigrasi ke dunia maya" sudah sangat kolosal. Survei yang dilakukan oleh Asosiasi Penyelenggara Jaringan Internet Indonesia (APJII) misalnya mengungkapkan bahwa lebih dari setengah penduduk Indonesia kini telah terhubung ke internet. Hal tersebut menuntut peran masyarakat untuk lebih cerdas memilih dan juga memilah informasi yang baik dan tepat untuk digunakan atau dimanfaatkan, disinilah literasi digital penting difahami dan diperlukan pembelajaran yang strategis untuk pengembangan pendidikan bidang ini di era cyber.

Praktik-praktik literasi akan memberikan makna dan fungsi tersendiri bagi pelakunya, bergantung kepada tujuan akhir yang akan diraih dan juga relasinya dengan orang-orang yang terlibat di dalam praktik tersebut. Literasi sebagai praktik sosial memiliki berbagai fungsi diantaranya untuk mengatur kehidupan sehari-hari, komunikasi personal, kesenangan pribadi, dokumentasi kehidupan pribadi, pemaknaan diri dan lingkungan dan juga sebagai partisipasi sosial.

\section{METODE}

Penyuluhan tentang pentingnya literasi digital dan kesadaran etika dalam bermedia sosial ini dilaksanakan pada bulan April 2021 lalu. Bertempat di Aula Utama Sekolah SMAN Wira Bangsa Aceh Barat, kami mengajak para siswa untuk berdiskusi sambil bermain tentang fenomena media sosial. Jumlah siswa yang hadir sekitar 20 orang. Diawali dengan menonton sebuah tayangan video sebagai pemantik diskusi tentang bermedia sosial, para siswa sangat antusias dalam menonton dan kemudian dilanjutan dengan sesi diskusi terhadap apa yang dapat dipelajari dari tanyangan tersebut.

Tayangan tersebut menampilkan bagaimana tokoh seperti Ade Armando dan musisi Ahmad Dhani sempat berurusan dengan pihak kepolisian akibat penyalahgunaan dalam bermedia sosial. Begitu juga dengan kabar kabar palsu/hoak dalam berbagai status yang dimunculkan dalam berbagai varian media sosial seperti Facebook, Twitter, Youtube dan sebagainya. 


\section{HASIL DAN PEMBAHASAN}

Adapun tahapan kegiatan dalam kegiatan ini adalah sebagai berikut:

1. Tahap Persiapan

Pada tahap ini, dilakukan koordinasi antara Tim yang akan melakukan pengabdian dengan Lembaga Penelitian dan Pengabdian Masyarakat Universitas Teuku Umar dalam upaya untuk menentukan mitra sasaran untuk dilakukannya kegiatan ini. Kemudian, setelah mitra sasaran sudah ditentukan tim menyusun jadwal dan tugas masing-masing anggota tim dalam mempersiapkan segala hal yang sudah dibgaikan dalam tugas masing-masing anggota tim. Mitra yang dijadikan sasaran kegiatan pengabdian ini adalah Sekolah Menengah Atas Negeri Wira Bangsa Aceh Barat. Tim kegiatan pengabdian kemudian bergerak menuju lokasi mitra untuk melakukan penjajakan dan proses administrasi. Pihak sekolah sepakat untuk dijadikan mitra sasaran serta setuju atas jadwal yang diusulkan oleh tim kegiatan. Jadwal yang disetujui oleh kedua belah pihak adalah tanggal 10 April 2021 bertempat di Aula Utama Sekolah tersebut. karena keadaan pandemi, prosedur kesehatan masih diberlakukan, sehingga jumlah peserta yang mengikuti kegiatan ini hanya dibatasi sebanyak 20 orang peserta.

2. Tahap pelaksanaan kegiatan

Kegiatan ini dilaksanakan di Aula Utama SMAN Wira Bangsa Aceh Barat pada tanggal 10 April 2021. Sesuai jadwal, acara tersebut dimulai dari pukul 09.00 WIB. Para peserta sudah berkumpul dalam ruangan sejak pukul 08.30 WIB. Tepat pukul 09.00 WIB acara pun dimulai. Kepala Sekolah memulai dengan pembukaan dan kemudian dilanjutkan dengan acara inti. Sempat terjadi kendala teknis, sehingga atas permintaan kepala sekolah proses penyuluhan akhirnya dipindahkan ke ruangan kelas.

Proses kegiatan berjalan cukup khidmat. Dimulai dengan tayangan video tentang bermedia sosial, para narasumber cukup serius dalam menjelaskan fenomena-fenomena dalam bermedia sosial. Hal ini didasarkan pada Penggunaan ponsel pintar saat ini bukan hanya sebagai alat komunikasi, tetapi juga bagian gaya hidup dan kebutuhan dasar masyarakat era digital. Indonesia telah menjadi salah satu negara melek teknologi informasi dalam beberapa dekade terakhir. Akan tetapi, kemajuan pesat tersebut tidak sejalan dengan tingkat literasi. Meskipun penggunaan media sosial memberi dampak positif, perkembangan media sosial ternyata juga dapat memberikan dampak negatif. Anak maupun remaja memiliki keterbatasan untuk melakukan regulasi diri. Mereka juga rentan mendapatkan tekanan dari teman sebaya sehingga mereka memiliki resiko tinggi terpapar dampak negatif dari penggunaan media sosial. Penelitian menunjukkan bahwa ada beberapa resiko yang mungkin didapatkan seperti terpaparnya konten pornografi atau konten negatif lain dan kurangnya pemahaman mengenai isu privasi. 


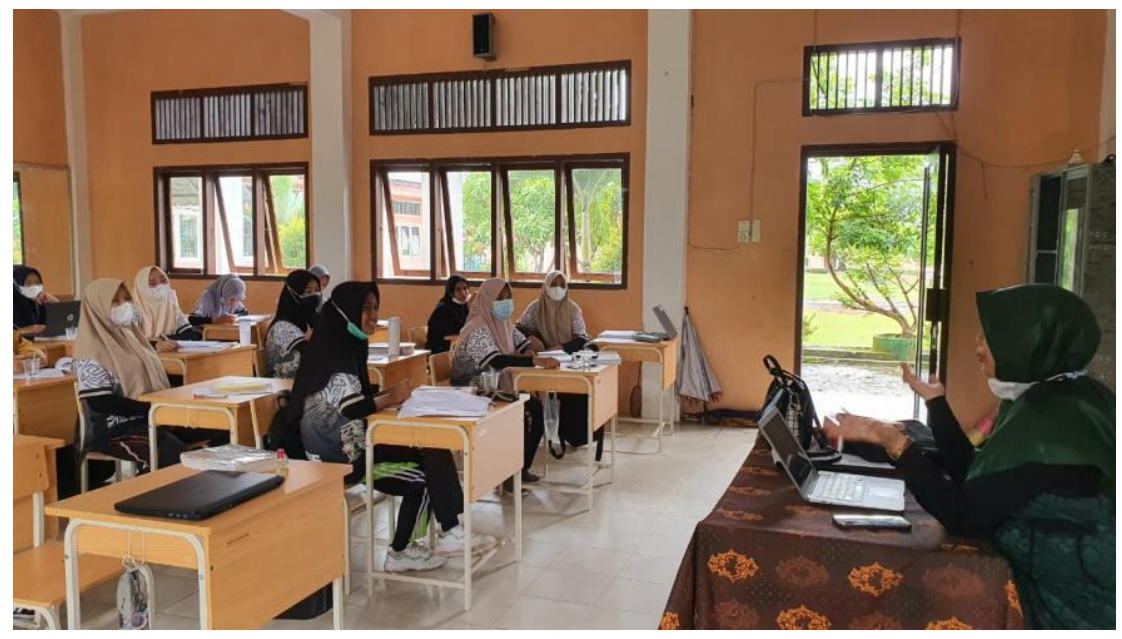

Gambar 1. Narasumber Sedang Memberikan Materi.

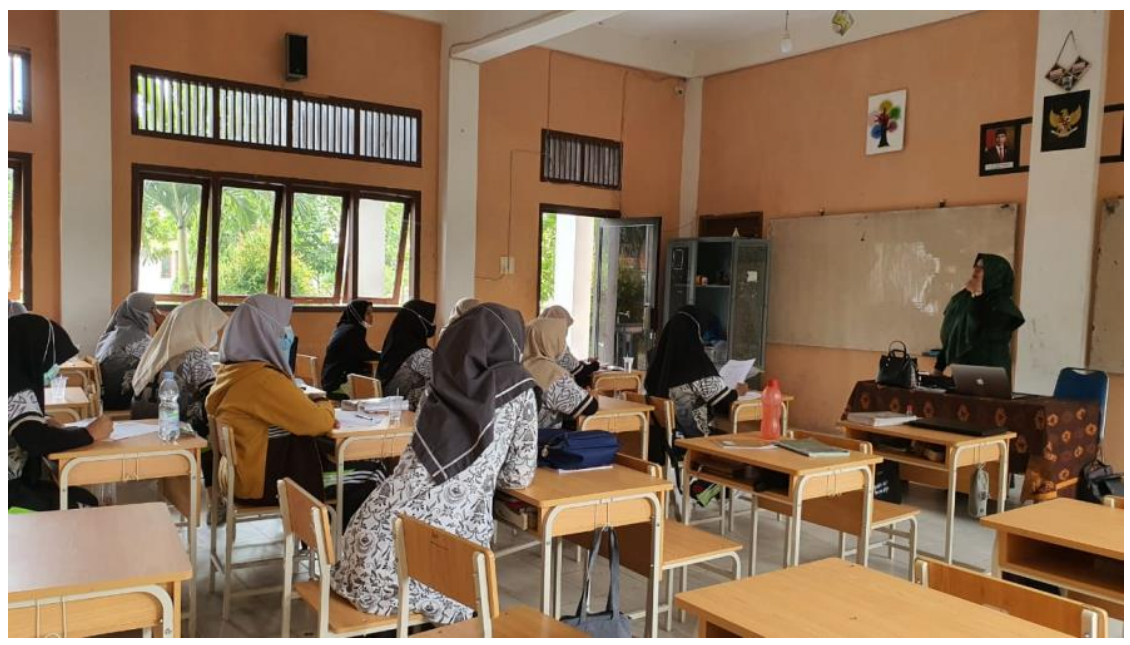

Gambar 2. Para Siswa Cukup Serius Dalam Mendengarkan Materi.

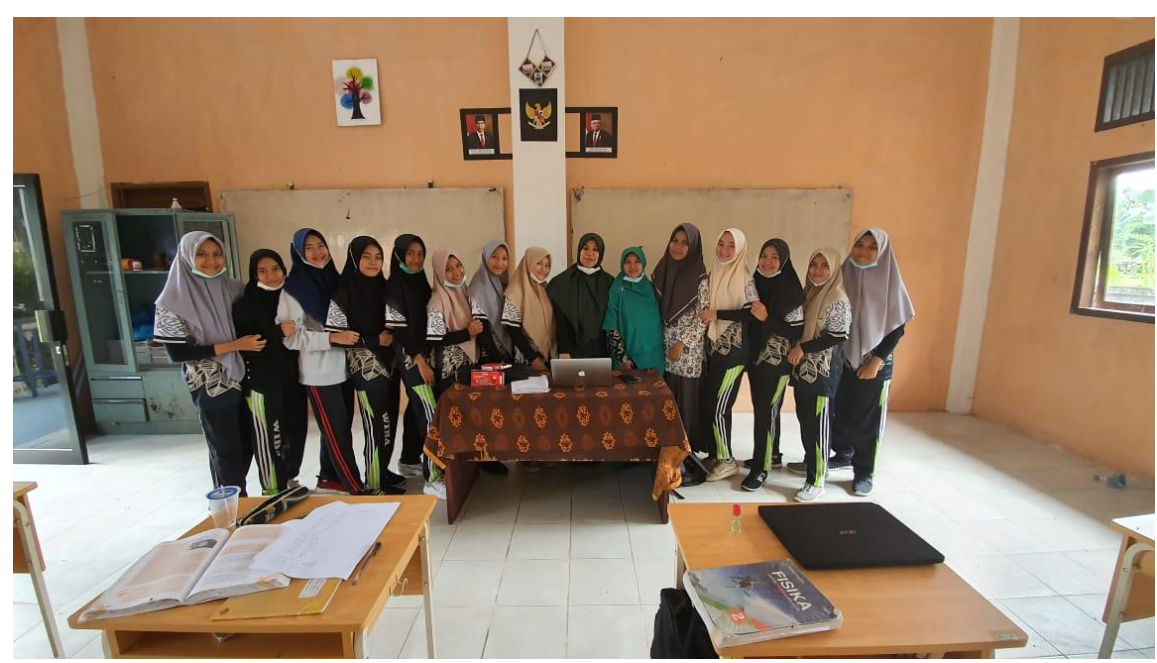

Gambar 3. Para Peserta Berfoto Bersama Narasumber Seusai Acara. 


\section{SIMPULAN}

Literasi digital menjadi kebutuhan mendesak bagi masyarakat saat ini. Sebab kemajuan teknologi yang tidak diimbangi oleh kecerdasan dalam menggunakan perangkat teknologi modern, niscaya akan memberikan dampak buruk bagi peradaban manusia. Dalam literasi digital itu bukan hanya sekedar kemampuan mencari, menggunakan dan menyebarkan informasi akan tetapi, diperlukan kemampuan dalam membuat informasi dan evaluasi kritis, ketepatan aplikasi yang digunakan dan pemahaman mendalam dari isi informasi yang terkandung dalam konten digital tersebut. Hal tersebut menuntut peran masyarakat untuk lebih cerdas memilih dan juga memilah informasi yang baik dan tepat untuk digunakan atau dimanfaatkan, disinilah literasi digital penting difahami dan diperlukan pembelajaran yang strategis untuk pengembangan pendidikan bidang ini di era cyber.

\section{UCAPAN TERIMAKASIH}

Kegiatan Pengabdian kepada Masyarakat ini terlaksana dari kerjama Universitas Teuku Umar dan Dinas Pendidikan dan Kebudayan Kabupaten Aceh Barat. Tim pelaksana ingin banyak mengucapkan terima kasih kepada seluruh pihak yang ikut memberikan dukungan sehingga kegiatan ini terlaksana dengan baik terutama pihak sekolah SMAN Wira Bangsa Aceh Barat. Tim pelaksana juga ingin mengucapkan terima kasih kepada Lembaga Penelitian dan Pengabdian Masayarakat Universitas Teuku Umar atas segala dukungan dan saran yang diberikan.

\section{DAFTAR PUSTAKA}

Casey, Leo dan Bruce, B. C. 2011. "The practice profile of inquiry: Connecting digital literacy and pedagogy." E-Learning and Digital Media 8(1).

Fitryarini, I. (2016). Literasi Media Pada Mahasiswa Prodi Ilmu Komunikasi Universitas Mulawarman. Jurnal Komunikasi, 8(1), 51-67.

Gilster, P., \& Watson, T. (1999). Digital Literacy Introduction to Excerpt. Retrieved from http://www.ncsu.edu/meridian/jul99/diglit/

Hidayatus Sholikhah, Octarina dan Lingga Nico Pradana. "Virtual Mathematics Kits (VMK): Mempromosikan Media Digital dalam Literasi Matematika." Jurnal Profesi Pendidikan Dasar 5(2).

Hobbs, R. (2010). Digital and Media Literacy: A Plan of Action. Journal of Craniofacial Surgery (Vol. 23). United States of America: The Aspen Institute.

Nurkhasanah, Guardian, Y., Sanjaya, \& Madyaningrum, E., (2015). Hubungan antara Tingkat Literasi Kesehatan dengan Self Efficacy pada Pasien Diabetes Mellitus Tipe 2 di Kabupaten Sleman, Skripsi, Universitas Gadjah Mada, Yogyakarta.

Safila, I., Guardian YK.., (2015). Hubungan antara Tingkat Literasi Kesehatan dengan Diabetes Self-Care Activities pada Pasien Diabetes Mellitus Tipe 2 di Kabupaten Sleman, Skripsi, Universitas Gadjah Mada, Yogyakarta.

Spires, Hiller dan Melissa E. Bartlett. 2012 Digital Literacies and Learning: Designing a Path Forward. North Carolina State University: The William \& Ida Friday Institute for Educational Innovation.

White, S. (2008). Assessing the Nation's Health Literacy. American Medical Association Foundation, Amerika Serikat. 